\title{
PENGARUH PENGGUNAAN MEDIA PEMBELAJARAN BERBASIS VIDEO TERHADAP HASIL BELAJAR MENGAIT PADA SISWA TATA BUSANA SMK NEGERI 8 MEDAN
}

\author{
Flora Hutapea ${ }^{1)}$ dan Nur Asmah Purba ${ }^{2)}$ \\ florahutapea@gmail.com
}

\begin{abstract}
Abstrak
Tujuanan dari penelitian ini adalah untuk mengetahui hasil belajar mengait yang tidak diberi media pembelajaran video dan untuk mengetahui hasil belajar mengait yang diberi media pembelajaran video pada siswa kelas X SMK Negeri 8 Medan yang telah dilaksanakan pada semester ganjil Tahun Ajaran 2013/2014, SMK Negeri 8 Medan, dengan jumlah populasi sebanyak 4 kelas (140 siswa). Metode yang digunakan dalam penelitian ini adalah metode eksperimensemu (Quasi Experiment). Hasil penelitian menunjukkan bahwa tingkat kecenderungan hasil belajar mengait siswa kelas X Tata Busana SMK Negeri 8 Medan pada kelas Eksperimen kategori cukup siswa yaitu 40\%. Tingkat kecenderungan hasil belajar mengait pada kelas kontrol kategori kurang yaitu 29\%. Untuk uji normalitas data menggunakan rumus chi-kuadrat pada taraf signifikan $5 \%$ dengan $\mathrm{dk}=35$, diperoleh hasil belajar Mengait kelas Eksperimen berdistribusi nomal, karena $X_{\text {hit }}<X_{\text {tab }}(-33,53<11,070)$ dan kelas Kontrol berdistribusi normal, karena $X_{\text {hit }}<X_{\text {tab }}(-26,22<11,070)$. Sedangkan uji homogenitas, diperoleh $\mathrm{F}_{\text {hit }}<\mathrm{F}_{\text {tal }}$ yaitu $1,05<2,65$ sehingga kedua kelas penelitian memiliki varians yang sama (homogen).

Hasil uji hipotesis yang menggunakan uji-t diperoleh nilai $t_{\text {hitung }}$ sebesar 8,07 sedangkan nilai $\mathrm{t}_{\mathrm{ab}}$ pada taraf signifikansi 5\% dengan $\mathrm{n} 68=$ sebesar 1,67. Dengan demikian $t_{\text {hit }}>t_{\text {tab }}(8,07>1,67)$. Oleh karena itu dapat disimpulkan bahwa terdapat Pengaruh Penggunaan Media Pembelajaran Berbasis video Terhadap Hasil Belajar Mengait pada siswa kelas X Tata Busana SMK Negeri 8 Medan.
\end{abstract}

Kata Kunci: Media Video dan Hasil Belajar Mengkait

\section{PENDAHULUAN}

Sekolah Menengah Kejuruan (SMK) merupakan lembaga pendidikan formal dalam bidang kejuruan. Tujuan Sekolah Menengah Kejuruan secara umum mengacu kepada isi Undang-Undang Sistem Pendidikan Nasional (UU SPN Tahun 2003) pasal 3 mengenai tujuan Pendidikan Nasional dan penjelasan pasal 15 yang menyebutkan bahwa pendidikan kejuruan merupakan pendidikan menengah yang mempersiapkan peserta didik terutama untuk bekerja dalam bidang tertentu.

SMK Negeri 8 Medan memiliki banyak program mata pelajaran produktif untuk mendukung tercapainya lulusan yang bermutu. Siswa menengah kejuruan diharapkan mampu menguasai setiap mata pelajaran karena setiap mata pelajaran mempunyai hubungan dan keterkaitan dengan mata pelajaran yang lainnya. Berdasarkan kurikulum program keahlian Tata Busana terdapat mata pelajaran tekstil yaitu salah satunya mengait. Melalui mata pelajaran tekstil mengait ini diharapkan siswa SMK dapat memiliki kemampuan dalam menerapkan tusuk-tusuk dasar kaitan dalam suatu produk.

Dari hasil observasi dan wawancara kepada guru mata pelajaran menyatakan bahwa nilai mata pelajaran mengait secara teori tentang arti mengait, mengenal macam-macam tusuk dasar mengait, dan membuat tususk-tusuk mengait dalam suatu produk mendapat hasil yang baik. 
Permasalahan mata pelajaran tekstil mengait adalah pada saat melakukan praktek, masih terlihat bahwa kemampuan dan kreativitas siswa dalam mengkait masih rendah, sehingga minat siswa dalam hal mengkait juga masih rendah, hal ini terlihat dari hasil belajar siswa seperti pada paparan dibawah ini.

Media Video adalah media utama untuk mendokumentasikan kejadian actual dan membawanya kedalam kelas, video memberikan kesempatan pada mereka atau siswa untuk mendiskusikan apa yang telah mereka saksikan secara bersama-sama. Dari uraian diatas, maka peneliti ingin mengetahui bagaimana Pengaruh Penggunaan Media Pembelajaran Berbasis Video Terhadap Hasil Belajar Mengait pada siswa kelas $X$ di SMK Negeri 8 Medan tahun ajaran 2013/2014.

Seperti dalam paparan diatas, maka menjadi cakupan masalah adalah sebagai berikut :

1. Bagaimana hasil belajar mengait yang tidak menggunakan media pembelajaran video pada siswa kelas $\mathrm{X}$ di SMK Negeri 8 Medan?

2. Bagaimana hasil belajar mengait yang menggunakan media pembelajaran video pada siswa kelas $\mathrm{X}$ di SMK Negeri 8 Medan?

3. Apakah ada pengaruh penggunaan media pembelajaran video terhadap hasil belajar mengai pada siswa kelas $\mathrm{X}$ di SMK Negeri 8 Medan?

Penelitian ini secara umum bertujuan untuk mengetahui pengaruh antara penggunaan media video dengan hasil belajar mengait. Selanjutnya tujuan tersebut dijabarkan secara khusus sesuai dengan rumusan masalah sebagai berikut:

1. Untuk mengetahui hasil belajar mengait yang tidak diberi media pembelajaran video pada siswa kelas $\mathrm{X}$ di SMK Negeri 8 Medan

2. Untuk mengetahui hasil belajar mengait yang diberi media pembelajaran video pada siswa kelas $X$ di SMK Negeri 8 Medan
3. Untuk mengetahui adanya pengaruh penggunaan pembelajaran video terhadap hasil belajar mengait pada siswa kelas X di SMK Negeri 8 Medan.

Hasil penelitian ini diharapkan dapat memberikan manfaat kepada semua pihak baik secara langsung maupun tidak langsung terutama dalam pengembangan pendidikan.

\section{KERANGKA TEORITIS}

Sanjaya (2010) mengatakan media pembelajaran adalah seluruh alat dan bahan yang dapat dipakai untuk tujuan pendidikan seperti radio, televise, buku, koran, majalah, komputer dan lain sebagainya. Selain alat-alat tersebut orang dan bahan serta peralatan yang menciptakan kondisi yang memungkinkan siswa memperoleh pengetahuan, kterampilan dan sikap juga disebut sebagai media pembelajaran.

Media pelajaran adalah perangkat lunak (software) berisi pesan atau informasi pendidikan yang biasanya disajikan dengan mempergunakan peralatan. Peralatan atau perangkat keras (hardware) merupakan sarana untuk dapat mengumpulkan pesan yang terkandung dalam media tersebut.

Berdasarkan penjelasan tentang pengertian media pembelajaran dapat disimpulkan bahwa media pembelajaran adalah segala sesuatu yang dapat digunakan untuk menyampaikan pesan atau materi yang mengandung tujuan instruksional kepada penerima pesan dalam pembelajaran, media pembelajaran merupakan segala sesuatu yang dapat digunakan untuk menyalurkan pesan, merangsang fikiran, perasaan, perhatian dan kemampuan siswa sehingga dapat mendorong keberhasilan proses belajar.

Untuk itu disimpulkan tujuan penggunaan media pembelajaran adalah membantu guru dalam menyampaikan pesan-pesan atau materi pelajaran kepada siswanya, agar pesan lebih mudah 
dimengerti, lebih menarik, dan lebih menyenangkan kepada siswa.

Berkaitan dengan manfaat media sebagai alat bantu, Djamarah (2010) menjelaskan sebagai berikut:

Setiap materi pelajaran memiiki tingkat kesukaran yang bervariasi. Pada satu sisi ada bahan pelajaran yang tidak memerlukan alat bantu, tetapi di lain pihak ada bahan pelajaran yang sangat memerlukan alat bantu berupa media pembelajaran seperti globe, grafik, gambar, slide presentasi dan lain sebagainya. Bahan pelajaran dengan tingkat kesukaran yang tinggi tentu sukar diproses oleh siswa apalagi bagi siswa yang kurang menyukai bahan pelajaran yang disampaikan tersebut.
Berdasarkan penjelasan tersebut media pembelajaran sebagai salah satu sumber belajar ikut membantu guru memperkaya wawasan siswa. Aneka macam bentuk dan jenis media pendidikan yang digunakan oleh guru menjadi sumber ilmu pengetahuan bagi siswa. Guru dalam menerangkan suatu benda dapat membawa bendanya secara langsung ke hadapan siswa di depan kelas. Apabila hal tersebut tidak dimungkinkan, guru dapat membuat sketsa dari benda tersebut sebagai sumber belajar.

Ada beberapa jenis media pembelajaran yang dapat digunakan seperti yang dikemukakan oleh Anderson (1976) media dapat dikelompokkan menjadi 10 golongan sebagai berikut :

Tabel 1. Jenis-jenis Media Pembelajaran.

\begin{tabular}{|l|l|}
\hline \multicolumn{1}{|c|}{ Golongan Media } & \multicolumn{1}{|c|}{ Contoh } \\
\hline Audio & Kaset audio, siaran radio, CD, telepon \\
\hline Cetak & Buku pelajaran, modul, brosur, leaflet, gambar \\
\hline Audio cetak vaset audio yang dilengkapi bahan tertulis \\
\hline $\begin{array}{l}\text { Proyeksi visual } \\
\text { diam }\end{array}$ & $\begin{array}{l}\text { Overhead transparansi (OHT), film bingkai } \\
\text { (slide) }\end{array}$ \\
\hline $\begin{array}{l}\text { Proyeksi audio } \\
\text { visual diam }\end{array}$ & Film bingkai bersuara \\
\hline Visual gerak & Film bisu \\
\hline Audio visual gerak & Film gerak bersuara, video / VCD, televisi \\
\hline $\begin{array}{l}\text { Obyek fisik } \\
\text { realita) }\end{array}$ & Benda nyata, model specimen \\
\hline Komputer dan & $\begin{array}{l}\text { CAI, (pembelajaran berbantuan computer) } \\
\text { lingkungan belajar, peristiwa, benda-benda } \\
\text { karya manusia, batu-batuan, flora dan fauna, } \\
\text { lingkungan }\end{array}$ \\
\hline
\end{tabular}

Video adalah media utama untuk mendokumentasikan kejadian actual dan membawanya kedalam kelas. Video dapat digunakan di semua lingkungan pembelajaran baik kelas, kelompok kecil maupun perorangan. Video sangat bagus untuk menunjukkan cara kerja suatu alat. Demonstrasi bisa jadi lebih mudah dengan media dibandingkan dengan praktek. Jika anda mengajar dengan langkah demi langkah suatu proses, anda dapat menunjukkan dengan waktu yang sesungguhnya, tetapi dengan media anda bisa mempercepat proses yang lama atau memperlambat untuk menunjukkan proses secara rinci.

Tujuan Pemanfaatan Program Video

1. Digunakan untuk menyampaikan informasi (toinform) yaitu Digunakan sebagai sarana untukmenyebarluaskan informasi dan pengetahuan yang diperlukan oleh pengguna Courtesy outube 
2. Untuk membelajarkan (to instruct), yaitu Dimanfaatkan untuk membelajarkan siswatentang keterampilan atau kompetensi yangbersifat spesifik.Bagi siswa SMK video pembelajaran mampudigunakan dalam

mendemonstrasikanbagaimana

keterampilan teknik dilakukan dengan benar.

3. Untuk membujuk (to persuade).

4. Untuk menghibur (to entertaint)

Definisi mengait menurut Bonita (2011) adalah teknik mengait menggunakan jarum dengan kait diujungnya, teknik kait ini menghasilkan jahitan yang berlubang-lubang menyerupai renda. Teknik ini menghasilkan jahitan yang lebih rapat. Mengait adalah suatu teknik membuat suatu bentuk dengan pertolongan jarum kait, dengan membentuk sengkelitsengkelit.

Mengait adalah teknik mengait dengan menggunakan satu jarum dengan ujung yang melengkung atau membentuk kait. Ujung yang melekung tersebut berguna untuk mengaitkan benang. Dalam Wikipedia (2010) mengait adalah metode membuat pakaian dengan menggunakan benang. Mengait hanya menggunakan sehelai benang. Untuk membuat ragam kreasi kaitan hanya dibutuhkan satu jarum dan beberapa gulung benang. Hasil kreasi mengait memiliki pola seperti rantairantai yang bersambungan. Saat ini kreasi mengait banyak jenisnya denganmemiliki ciri khas yang beragam produk mengait seperti lenan rumah tangga, aksesories, perlengkapan bayi, dan boneka yang terus berkembang dari waktu ke waktu. Bahan-bahan untuk mengait antara lain adalag; Benang
Rajut/kait, Benang Jahit, Dakron, dan Aksesoris Tambahan yang dibutuhkan dan digunakan sesuai dengan kreasi pernak-pernik yang dibuat.

\section{Cara Membuat Bros Bunga Mawar} dari Kaitan

1. Buatlah 25 ch dengan memakai benang rajut berwarna orange sembur. Sambungkan ke ch yang pertama sehingga membentuk lingkaran

2. Kemudian buatlah24 sc dimulai dari ch ke-2 dari hakpen

3. Buatlah kelopak tingkat ke-1 yaitu : $2 \mathrm{ch}, 3 \mathrm{dc}, 2 \mathrm{ch}$, ss (slip stich) ulangi sampai dengan mengelilingi lingkaran dengan jarak (1 kelopak = $1 \mathrm{sc}$ ) sehingga menghasilkan 11 kelopak

4. Buatlah 3 ch pada setiap bagian belakang kelopak yang berguna untuk membuat kelopak pada tingkat ke-2

5. Kemudian buatlah kelopak tingkat ke-2 yaitu : $2 \mathrm{ch}, 1 \mathrm{dc}, 3 \mathrm{Tr}, 1 \mathrm{dc}$, $2 \mathrm{ch}$, lalu ss (slpi stich). Ulangi sampai mengelilingi lingkaran sehingga menghasilkan 11 kelopak

6. Selanjutnya buatlah Buatlah 5 ch pada setiap bagian belakang kelopak yang berguna untuk membuat kelopak pada tingkat ke3

7. Kemudian buatlah kelopak tingkat ke-3 yaitu : 2 ch, 1 dc, 1 Tr, 3 puff of $3 \mathrm{dc}, 1 \mathrm{Tr}, 1 \mathrm{dc}, 2 \mathrm{ch}$, lalu ss (slpi stich). Ulangi sampai mengelilingi lingkaran sehingga menghasilkan 11 kelopak

8. Jahitlah mutiara pada bagian tengah bunga dengan menggunakan jarum dan benang jahit, kemudian tempelkan flanel dan peniti bros pada bagian bawah /belakang bunga, dan bunga mawar selesai dikait. 
Berdasarkan kerangka berfikir diatas, maka yang menjadi hipotesis dalam penelitian ini adalah adanya Pengaruh Penggunaan Media

\section{METODE PENELITIAN}

Metode penelitian adalah salah satu cara yang dipergunakan untuk mencapai tujuan penelitian. Tujuan yang dimaksud adalah untuk menguji serangkaian hipotesis dengan pengetahuan metode atau cara yang dipakai dalam penelitian, maka dengan sendirinya mudah untuk memperoleh data yang dibutuhkan. Metode yang digunakan
Pembelajaran Berbasis Video Terhadap Hasil Belajar Mengait pada siswa kelas $\mathrm{X}$ di SMK Negeri 8 Medan Tahun Ajaran 2013/2014.

dalam penelitian ini adalah metode penelitian eksperimen semu (Quasi Experiment), agar dapat melihat pengaruh penggunaan media pembelajaran video terhadap hasil belajar mengait pada siswa kelas $\mathrm{X}$ di SMK Negeri 8 Medan. Populasi penelitian ini adalah seluruh kelas XI Tata Busana SMK Negeri 8 Medan Tahun Ajaran 2013/2014 yakni :

Tabel 3. Jumlah Populasi Penelitian

\begin{tabular}{|l|l|l|}
\hline No & Kelas & Jumlah \\
\hline 1 & $\mathrm{X}-1$ & 35 siswa \\
\hline 2 & $\mathrm{X}-2$ & 35 siswa \\
\hline 3 & $\mathrm{X}-3$ & 35 siswa \\
\hline 4 & $\mathrm{X}-4$ & 35 siswa \\
\hline Jumlah & 140 siswa \\
\hline
\end{tabular}

Teknik pengambilan sampel pada penelitian ini adalah menggunakan teknik Purposive Sample, dengan demikian peneliti menentukan kelas XI-3 dan XI-4 sebagai sampel

\begin{tabular}{|l|l|l|}
\hline No & Kelas & Jumlah \\
\hline 1 & XI-3 & 35 siswa \\
\hline 2 & XI-4 & 35 siswa \\
\hline \multicolumn{2}{|l|}{ Jumlah } & 70 siswa \\
\hline
\end{tabular}

Instrumen yang digunakan untuk menjaring data hasil belajar mengait yaitu melalui Lembaran pengamatan yang telah disusun sebelumnya dan kemudian diamati oleh lima orang pengamat dimana kelima pengamat (observer) dianggap ahli dalam bidang mengait dan layak untuk mengisi lembar penilaian.

Langkah-langkah yang harus ditempuh untuk mengetahui sejauhmana pengaruh hasil belajar penelitian, dengan alasan bahwa kedua kelas sampel tersebut rata-rata siswa memiliki kemampuan mengait yang sama.

Tabel 4. Jumlah sampel penelitian

siswa dalammata pelajaran mengait denganmenggunakan yang akan diajarkan kepada siswa di SMK Negeri 8 Medan adalah sebagai berikut:

a. Observasi

b. Menyusun RPP

c. Menggunakan media video pada mata pelajaran mengkait

d. Praktek mengkait

e. Hasil mengkait 
Untuk dapat memberikan gambaran terhadap data penelitian yang diperoleh, maka terlebih dahulu maka dihitung besaran rata-rata skor (Mean) dan standart deviasi (SD) sebagai berikut

1. Menentukan nilai rata-rata masing-masing kelompok (Irianto, 2009):

$$
\mathrm{M}=\frac{\sum X}{N}
$$

2. Menghitung standar devisiasi kelas kontrol dan kelas eksperimen:

$$
\begin{aligned}
& \mathrm{SD}= \\
& \frac{1^{2}}{n} \bar{N} X^{2}-(X)^{2}
\end{aligned}
$$

3. Distribusi Frekuensi

$$
\begin{aligned}
& \text { Rentang Skor }=\quad \text { skor } \\
& \text { tertinggi }- \text { skor terendah } \\
& \text { Banyak Kelas }=1+(3,3) \log \\
& \mathrm{N} \\
& \text { Panjang Kelas } \quad(\mathrm{P})= \\
& \frac{\text { rentangan }(R)}{\text { Jumlah kelas }(K)}
\end{aligned}
$$

Untuk menentukan tingkat kecenderungan setiap data variabel penelitian dianalisis dengan menggunakan harga rerata ideal $\left(M_{i}\right)$ dan standart deviasi ideal $\left(S D_{i}\right)$ dengan rumus sebagai berikut :

$$
\begin{aligned}
& M_{i=\frac{N_{r}-N_{t}}{2}} \\
& S D_{i=\frac{N_{r}-N_{t}}{6}}
\end{aligned}
$$

keterangan

$M_{i}=$ rata-rata ideal

$S D_{i}=$ simpangan baku ideal

$N_{r}=$ nilai terendah ideal

$N_{t}=$ nilai tertinggi ideal

Untuk mengetahui apakah komponen yang disusun layak dipakai untuk menjaring data yang sebenarnya maka terlebih dahulu dilakukan uji kesepakatan menggunakan analisis varian satu arah (ANAVA Satu Arah) dengan taraf signifikan $5 \%$, dengan rumus sebagai berikut :

$$
F_{o}=\frac{M K_{\text {antara }}}{M K_{\text {dalam }}}
$$

Bila besaran $F_{\text {observasi }}<F_{\text {otabel }}$ dengan taraf signifikan 5\%, maka dapat disimpulkan bahwa tidak ada perbedaan hasil penilaian dari kelima pengamat. Dengan demikian maka butir-butir komponen yang disusun dapat digunakanuntuk menjaring data penelitian

\section{HASIL PENELITIAN}

Berdasarkan data yang diperoleh dari hasil penelitian dengan 35 sampel terdapat skor tertinggi 81 dan skor terendah 46dengan ratarata (M) adalah 65,54 dan standar deviasi (SD) adalah 9,83.

Tabel 8.Distribusi Frekuensi Variabel Belajar Mengait pada Kelas Eksperimen

\begin{tabular}{|l|l|l|l|}
\hline Kelas & Interval Kelas & F. Absolut & $\begin{array}{c}\text { F. Relatif } \\
(\%)\end{array}$ \\
\hline 1 & $76-81$ & 3 & 9 \\
\hline 2 & $70-75$ & 6 & 17 \\
\hline 3 & $64-69$ & 11 & 31 \\
\hline 4 & $58-53$ & 7 & 20 \\
\hline 5 & $52-57$ & 6 & 17 \\
\hline 6 & $46-51$ & 2 & 6 \\
\hline \multicolumn{2}{|l}{ Jumlah } & 35 & 100 \\
\hline
\end{tabular}

Pengaruh Penggunaan Media Pembelajaran Berbasis Video Terhadap Hasil Belajar -63 
Berdasarkan data dari tabel 5, maka data dapat digambarkan dalam bentuk histogram sebagai berikut :

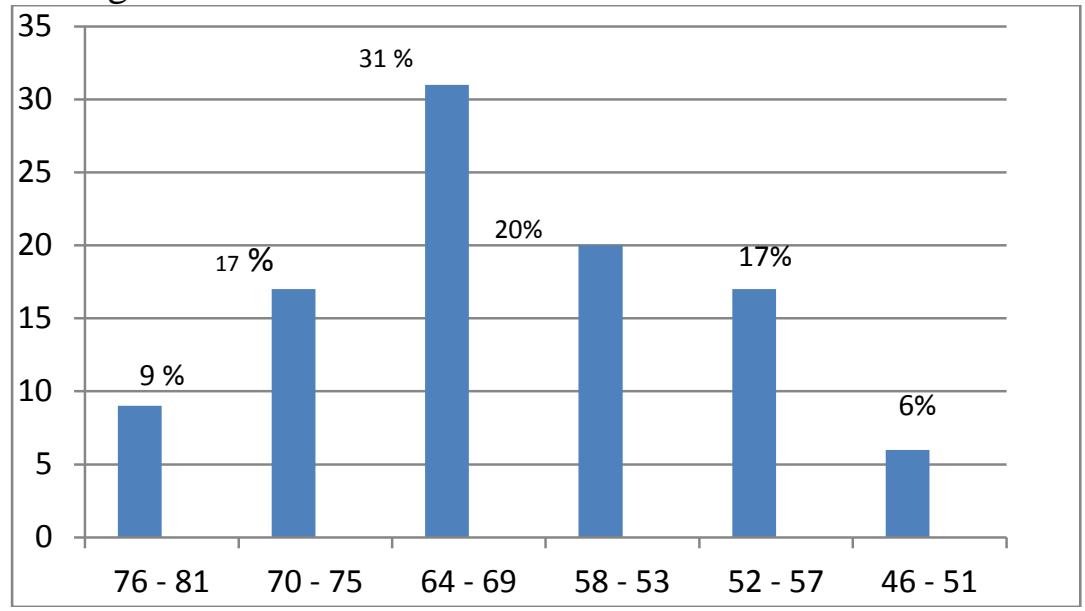

Adapun hipotesis dalam penelitian ini adalah Pengaruh Penggunaan Media Pembelajaran Berbasis Video Terhadap Hasil Belajar Mengait Pada Siswa Kelas X Tata Busana di SMK Negeri 8 Medan Tahun 2013/2014.

Untuk menguji hipotesis dilakukan menggunakan rumus uji-t. Kriteria pengujian adalah $\mathrm{H}_{0}$ diterima jika $t_{\text {hi }}>t_{\text {tab. }}$. Berdasarkan hasil perhitungan dengan menggunakan uji-t, diperoleh $t_{h i t}=8,07$. Setelah dikonsultasikan dengan $t_{\text {tabel }}=1,67$ pada taraf signifikansi 5\% maka $t_{\text {hit }}>t_{\text {tab }}=8,07>1,67$ Sesuai dengan kriteria penerimaan atau penolakan hipotesis, maka hipotesis alternatif $\left(\mathrm{H}_{\mathrm{a}}\right)$ dapat diterima pada taraf signifikansi 5\%, dengan demikian dinyatakan bahwa "Ada Pengaruh Hasil Belajar Mengait Menggunakan Media Pembelajaran Berbasis Video Pada Siswa kelas X Tata Busana SMK Negeri 8 Medan Tahun Ajaran 2013/2014. Setelah nilai $F_{\text {hit }}=0,59$ diperoleh, maka dikonsultasikan dengan $\mathrm{F}_{\text {tabel }}$ pada taraf signifikansi $5 \%$ dengan $\mathrm{dk}=4: 30$ diperoleh $\mathrm{F}_{\text {tab }}$ $=2,64$. Oleh karena itu, $F_{\text {hit }}<F_{\text {tab }}$ $(0,59<2,64)$. Dengan demikian dapat disimpulkan bahwa tidak terdapat perbedaan yang signifikan dalam hasil penilaian diantara kelima pengamat, serta terdapat kesamaan pemahaman dalam memahami butirbutir kriteria pengamatan.

Kemudian hasil perhitungan yang diperoleh dari data hasil belajar mengait pada kelas eksperimen memperoleh rata-rata nilai 65,54 dengan nilai tertinggi ideal 81dan standar deviasi 9,83, sedangkan pada kelas kontrol memperoleh rata-rata nilai 57,31 dengan nilai tertinggi ideal 76 dan standar deviasi 9,32.

Penelitian ini diperkuat dengan hasil penelitian yang dilakukan Sudjana (2005) yang menyatakan bahwa media pembelajaran dapat mempertinggi proses belajar siswa sehingga dapat mempertinggi hasil belajar siswa.

\section{Kesimpulan}

Berdasarkan hasil penelitian yang diuraikan pada bab sebelumnya, maka dapat ditarik kesimpulan sebagai berikut :

1. Hasil belajar mengait pada kelas eksperimen berada pada kategori cukup dengan presentase $40 \%$ dan data hasil penelitian tentang 
hasil belajar mengait pada kelas kontrol berada pada kategori rata-rata pada nilai 65,54 dan $\mathrm{Sd}$ 9,83.

2. Hasil belajar mengait pada kelas kontrol berada pada kategori kurang dengan presentase $29 \%$ dan data hasil penelitian tentang hasil belajar mengait pada kelas kontrol berada pada kategori rata-rata pada nilai 57,31 dan $\mathrm{Sd}$ 9,32.

3. Hasil uji hipotesis menyatakan terdapat pengaruh penggunaan media video terhadap hasil belajar mengait di kelas X SMK Negeri 8 Medan pada taraf signifikansi $5 \%$ dapat diterima Saran dengan nilai $\mathrm{t}_{\mathrm{hit}}=8,07>\mathrm{t}_{\mathrm{tab}}=1,67$.

$\begin{array}{rr}\text { Untuk } & \text { perbaikan } \\ \text { pembelajaran } & \text { yang }\end{array}$ dimanfaatkan oleh semua dan untuk penelitian selanjutnya, ada beberapa saran yang diberikan antara lain :

1. Sebaiknya media pembelajaran harus selalu di manfaatkan oleh guru dalam proses belajar mengajar sehingga hasil belajar mengkait dapat terus ditingkatkan.

2. Setiap pembelajaran memberi makna yang berbeda oleh karena itu pemanfaatan media belajar harus terus ditingkatkan dan tidak hanya terfokus pada mata pelajaran mengkait.

3. Para guru diharap lebih banyak lagi menguasai penggunaan media pembelajaran yang lain untuk menciptakan suasana belajar mengajar yang menarik, inovatif, dan kreatif, sehingga memunculkan minat belajar siswa yang lebih baik lagi.

\section{DAFTAR PUSTAKA}

Arsyad. 2011. Media Pembelajaran. PT. Raja Grafindo Persada : Jakarta

Arikunto, 2010. Prosedur Penelitian. PT. Bumi Aksara : Jakarta

Ayuningrum, Fiskha, 2012. Pengembangan Media Video Pembelajaran untuk Siswa Kelas $\mathrm{X}$ pada Kompetensi Mengolah Soup Kontinental di SMK N 2 Godean T.A 2012/2013.

Bonita, 2011. Merajut. PT. Kriya Pustaka : Jakarta

Djamarah. 2006. Strategi Belajar. PT. Rhineka Cipta : Jakarta

Djamarah. 2010. Media Pembelajaran. PT. Rhineka Cipta : Jakarta

Dimyati. 2006. Belajar dan Pembelajaran. PT. Rhineka Cipta : Jakarta

Hamalik, 2006. Proses Belajar Mengajar. PT. Buku Kompas : Jakarta

Hujair AH. Sanaky, 2013. Media Pembelajaran Interaktif-Inovatif. PT. Kaukaba Dipantara : Yogyakarta.

Irianto, 2009. Statistik Konsep Dasar. PT. Kencana Prenada Media Group : Jakarta

Munadi, Yudhi. November 2008. Media Pembelajaran. Gaung persada press: Ciputat.

Nasution, 2010. Hasil Belajar Mengajar. PT. Ghalia Indonesia : Jakarta

Pang, Thata, 2012. Pernak - Pernik Rajutan. PT. Kriya Pustaka : Jakarta.

Poerwanto, 2009. Evaluasi Belajar Mengajar. PT. Pustaka Pelajar : Yogyakarta

Prajogo, Marnata, 2011. Fashion Crochet. PT. Trubus Agrisarana : Surabaya 
Riduwan, 2010. Metode Penelitian. PT. Bumi Aksara : Jakarta

Riyana. 2008. Media Pendidikan. PT. Raja Grafindo Persada : Jakarta

Sadiman, Arief, Dr.,M.sc., 2005. Media Pembelajaran. PT. Grafindo persada: Jakarta.

Sidharta, Yenny, 2011. Crochet Bag. PT. Trubus Agrisarana : Surabaya Sudjana, 2005. Hasil Proses Belajar Mengajar. PT. Remaja Rosdikarya : Bandung

Sugiyono, 2008. Prosedur Penelitian. PT. Bumi Aksara : Jakarta

Sumiati, 2008. Media Pembelajaran. PT. Wacana Prima : Bandung

Thobroni, 2011. Belajar dan Pembelajaran. PT. AR-RUZX Media : Yogyakarta

Wibowo, Yuniar, 2013. Seri Merajut Casual Bag Crochet. PT. Trubus Agrisarana: Surabaya. 